\title{
Comprehensive evaluation of interior lighting
}

\begin{abstract}
Paper deals with problematic of evaluation artificial and daylight as one medium. By this assumption we have to deal with the different evaluation of each lighting system. Whereas artificial light is evaluated by the measured or calculated value of illuminance stated in lux, daylight is evaluated by the value of daylight factor expressed in \%. In paper is discussed the example of the possible lighting calculation by using the light vector to define illuminance in the field of rectangular light source such as window, problematic of various conditions of daylight and possible using of this method.
\end{abstract}

Keywords: artificial light, daylight, vertical illuminance, illuminance in the field of rectangular light source.

\section{Introduction}

The human body is accustomed to regular patterns of light and darkness during the day and year already from the beginning of human being. Even biological processes of human body were adapted to this process during evolution.

The progressive moving of the human activity from outside to the indoor environment was mainly caused by the ability to use light and create the acceptable conditions for certain activity elsewhere then under the open sky.

\section{Importance of light}

The ability to use light raised the question of need to ensure and adequately control the lighting conditions for execution of work in the interior.

Nowadays in the Czech Republic, we are designing artificial light at the workplaces according to the national version of European standard ČSN EN 12 464-1, which lists the parameters for artificial lighting design. The requirements for residential area lighting were overridden. A separate standard for artificial lighting of residential was abolished in 2005 and there are only fragments of this standard forming the supplements of civil engineering standard ČSN 734301 in force now.

With the advent of modern age together with its needs of electric energy savings, we should think about the possibility of saving energy right by the lighting the space whether workplaces or residential. Today we are able to build low-carbon or even zero-carbon buildings, we are able to invest large amounts in building insulation save energy on heating and progressively through efficient appliances we should also focus on the possibility of saving energy by efficient lighting.

Efficient lighting does not mean just efficient lamps, but also efficient lighting design [1].

According to research people spend nowadays, especially in cities, $90 \%$ of their time in the buildings. The appropriate design of the artificial lighting, or the automatic lighting control system can offer to us a significant potential of energy savings.

\section{Interior lighting design}

The easiest way how to save the energy on lighting is to look at the interior lighting together from both sides.

1) Artificial light - lighting system ensures enough light for the work and parameters of the system are designed according to legislation to ensure the minimum stated values for the activity.

2) Daylight - from our point of view the window is a luminaire with variable power during the day in accordance with the outside weather conditions.

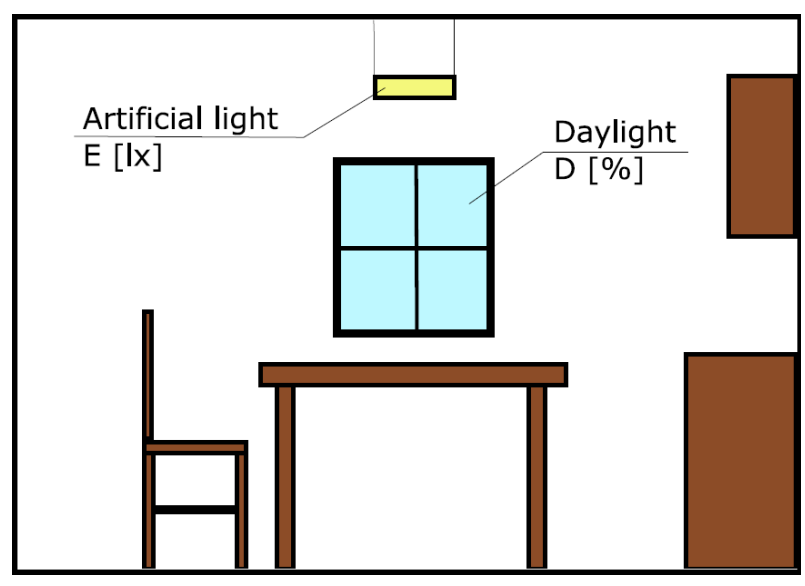

Fig.1. Evaluation of artificial light and daylight

By this assumption we have to deal with the different evaluation of each lighting system. Whereas artificial light is evaluated by the measured or calculated value of illuminance $\mathrm{E}$ stated in lux, daylight is evaluated by the value of daylight factor $D$ expressed in \%.

Due to the different form of expressing daylight and artificial light, there is low chance to keep both parameters together and use them efficiently for the lighting design, although both evaluation methodologies are sufficient and well working for its own area. One of the possible way, how to keep both parts of light and consider all advantages arising from both parts in the lighting design is look at it unified.

\section{Window as a luminaire}

If we consider the window as a luminaire, we can use the parameters of the light field to express the illuminance in the field of window as a rectangular light source.

C

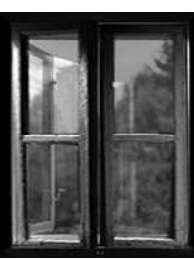

d

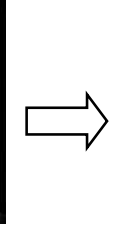

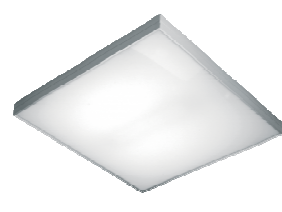

C d
Fig.2. Possibility of conversion of the window to the luminaire 
For simplicity we can assume window with the view of unobstructed part of the overcast sky with constant luminance conditions. This assumption ensures the simplification of the presented procedure. In case this assumption will not be passing, the window area would have to be divided into other several parts, where the assumption will be fulfilled.

An example of the possible considered calculation is by using the light vector to define illuminance in the field of rectangular light source such as window for us and state illuminance values at various control points in the room.

(1)

$\overrightarrow{d \varepsilon}=d E_{N}=L_{0} \cdot \sin ^{q} \gamma \cdot \cos ^{n} \gamma \cdot \cos \gamma \frac{1}{l^{2}} \cdot d A$

Where: $\overrightarrow{d \varepsilon}$ - size of the illuminance vector at the selected point $\mathrm{P}, d E_{N}$ - the normal illuminance at a selected point $\mathrm{P}$, $L_{0}$ - luminance of the element $d A$ in the direction of reference (the normal direction $N_{d A}$ ), $\sin ^{q} \gamma \cdot \cos ^{n} \gamma-$ characteristic function describing the considered curve of luminance.

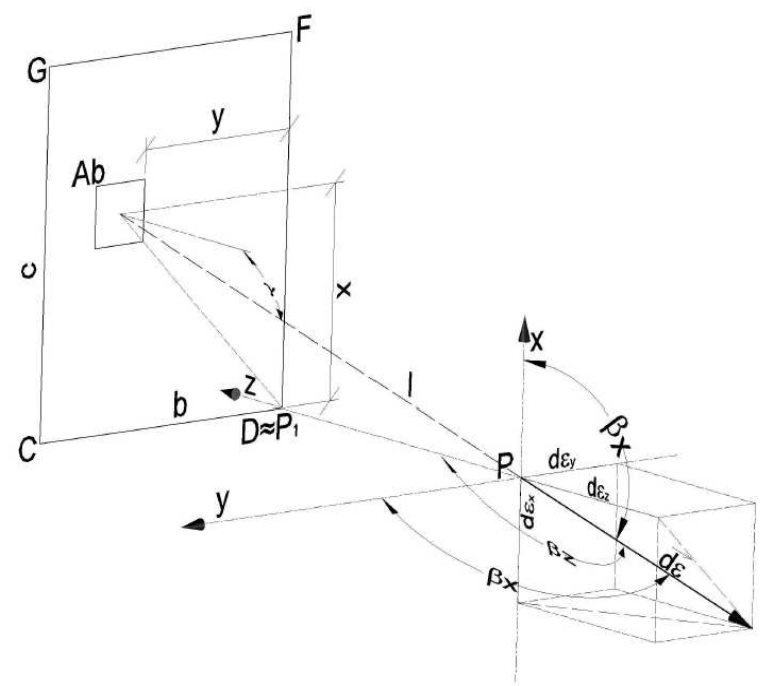

Fig.3. Calculation scheme of the illuminance in the field of rectangular light source

\section{Daylight}

For the ability to express the lighting-technical quantities of the window as a luminaire we have to deal more with the daylight parameters. The important part is to determine the horizontal illuminance of unobstructed plane for the whole set of CIE standard skies. These values than convert to an illuminance of vertical plane, which can represent in this case the building facade.

Last but not least it is needed the determination of the luminance values for the sky element, which are used on for the light calculations in the example.

Following figure shows a schematic model representing the room where a model calculation was made.

Illuminance was calculated at the point $P$ at the room with one window ( $2 \mathrm{~m}$ height and all wall width) with a window sill height $1 \mathrm{~m}$, which was also a height of the control point $P$ (workplane). The values of epsilon marking the individual projections of the light vector to the chosen coordinate axes, where in this case y represents the horizontal illuminance at the point $P$.

With a value of luminance measured as an average luminance value for the overcast sky, the results of illuminance is approx. 830lx, which was close to the value measured in the room by the appropriate exterior lighting conditions.

\section{Horizontal illuminance calculation}

Following figure is showing the scheme of the calculation, when there is rectangular luminaire instead of the window. The equations for the illuminance vector $\varepsilon y$, which in this case represents the horizontal illuminance, are stated below (2). The overall value of the vector $\varepsilon y$ is then summary of the individual parts of the rectangle which take into the account the effect of the position of the control point $P$ on the work plane.

Whole wall is divided into several parts represented by rectangles, where every rectangle has one corner on the projection of the evaluated point $P$. This kind of segmentation pass the rule for the illuminance calculation in the rectangular filed that one corner of the rectangular has to be on the projection to the point $P$ and this point is also the beginning of the coordinate system.

By the addition and subtraction of the individual rectangular fields will be given as a result just the hatched field representing the window area, which is part of the wall providing the contribution to the overall illuminance.

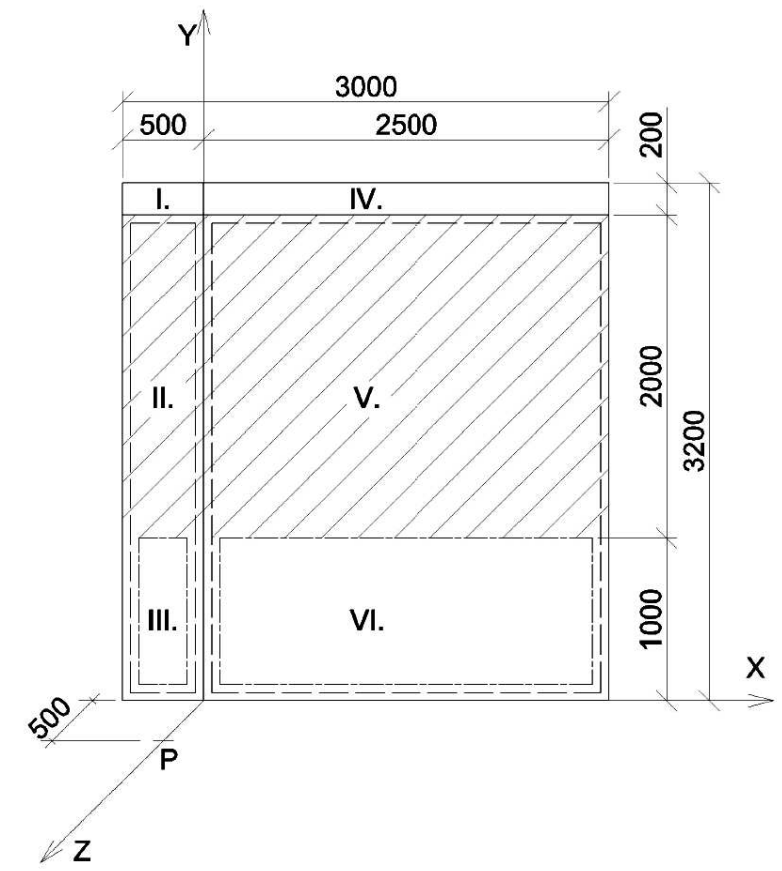

Fig.4. Horizontal illuminance calculation scheme - elevation

Hatched rectangles (II., V.) at the figure 4. are substituting the window area, rectangles I. and IV. together represents the overall dimensions of the wall, numbers III. and VI. represents the window sill.

Following figure 5 . Is showing the plane of the chosen situation for the calculation, together with the calculation points. 


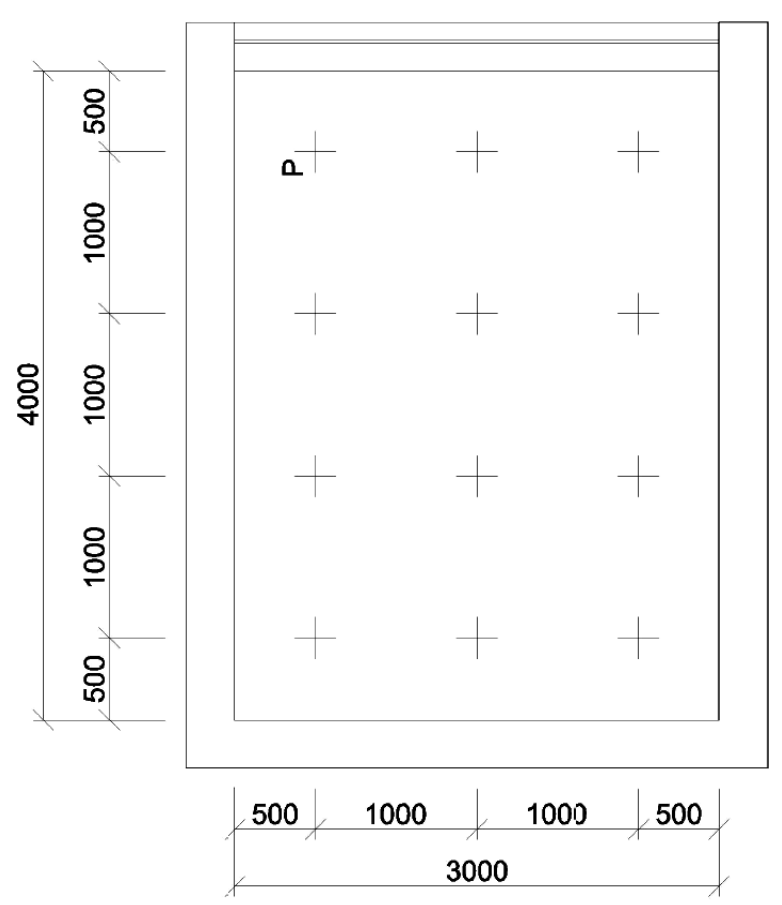

Fig.5. Horizontal illuminance calculation scheme - plan

With the considered assumption stated above, we can get the following equations.

(2)

$\varepsilon_{y}=\varepsilon_{y I}+\varepsilon_{y I V}-\left(\varepsilon_{y I}-\varepsilon_{y I I}\right)-\varepsilon_{y I I I}\left(\varepsilon_{y I V}-\varepsilon_{y V}\right)-\varepsilon_{y V I}$

$=\varepsilon_{y I I}+\varepsilon_{y V}-\varepsilon_{y I I I}-\varepsilon_{y V I}$

$\varepsilon_{y i}=L_{0} \cdot \frac{1}{2}\left[\operatorname{arctg} a-\frac{1}{\sqrt{1+b^{2}}} \cdot \operatorname{arctg} \frac{a}{\sqrt{1+b^{2}}}\right]$

Where: $a, b$ are considered as a relative dimensions (3).

(3)

$$
\begin{aligned}
& a=c / h \\
& b=d / h
\end{aligned}
$$

Where: $\mathrm{c}, \mathrm{d}, \mathrm{h}$ are dimensions of a considered luminaire.

After substituting into equation, where the value of luminance was assumed $L_{0}=3000 \mathrm{~cd} / \mathrm{m}^{2}$ the result for the $P$ point, placed $0,5 \mathrm{~m}$ from the left side and $0,5 \mathrm{~m}$ from the window was:

(4)

$\varepsilon_{y i}=E_{[0,5 ; 0,5]}=843,9 l x$

The result (4) corresponds with the verification measurement in the reference room with $10 \%$ accuracy. This was caused by simplifying the calculation of neglecting the influence of the surrounding buildings.
The input parameters for the calculation can be taken from measurements or calculations stated in papers [2], [3], [4], [5] which was already published.

\section{Other possible parameters}

Except the lighting parameters of luminaire already stated, there can be considered another set of parameters. Within the parameters defining the window as a luminaire could be also given the temperature parameters. As well as addressing the thermal conditions of the normal luminaire even the window opening is influenced by changes in outdoor temperature during the year. These changes can be described as a heat gains and loses varying during the year.

Even though the thermal parameters of the window are varying during the year and greatly influences the thermal comfort of the space, thermal parameters of a window as a luminaire can be considered as the maximum heat gains or heat loses during the year.

The question is which calculations would be the right one to use for the evaluation. There are now many ways of how to count the heat gains for the air conditioning design, but they are considering just some monthly values of temperature during the year. On the other hand the detailed modeling of weather conditions is not meeting the needs of the overall calculation.

One possible way for expression of thermal parameters is approach in accordance with standard ČSN 730548 or designing of the air-conditioning units. The procedure consists of two parameters. Transmission of heat through window by convection and by radiation.

In 2003 was published research from University of Ljubljana, where there was described a procedure of determining luminous intensity curves of window opening. Using the calculated spatial luminance distribution in accordance with CIE standards, they obtain photometric data for a light source which substitutes a window for which daylight illuminance should be determined. Photometric data are then calculated and written down in a standard way, using luminous intensity in C-planes. [7]

\section{Conclusion}

The presented assessment where the combination of artificial and natural light is used, based on detailed studies of individual components of light is not developed. Analysis of the potential contribution of daylight that we can identify and take into account when designing a set of artificial lighting can be an important part of energy savings. The system of artificial lighting must in any case comply with legislative requirements. The designer may however, in the context of lighting system design, take into account the contribution of daylight and artificial light and save the energy by using the lighting system during the day compared to the current use of the system. 


\section{References}

REFERENCES
[1] Škoda, J; Baxant, P.: The reduction in electricity consumption through proper lighting, EPE - Electric Power Engineering 2009, p. 1-5 (2009), ISBN 978-80-248-1947-1

[2] Darula, S., Kittler, R.: Parametrisation of the Four Half-Day Daylight Situations, Sustainable Growth and Applications in Renewable Energy Sources, InTech, (2011), ISBN 978-953307-408-5

[3] Pelánová, Z., Zálešák, J.: Horizontální osvětlenost v průběhu roku v podmínkách standardizovaných obloh CIE, LUMEN V4, MEE Világítástechnikai Társaság, 415-421 (2014), ISBN 978963-9299-21-4

[4] Pelánová, Z., Zálešák, J., Pavlousek, J., Bayer, R.: Osvětlenost vertikální nezacloněné roviny, Kurz osvětlovací techniky XXXI., Ostrava: Česká společnost pro osvětlování, 222-225 (2014), Czech republic, ISBN 978-80-248-3553-2

[5] Pelánová, Z.: Určení jasu oblohového elementu, Proceedings of ELEN 2014, Praha: ČVUT FEL, (2014), Czech republic, ISBN 978-80-01-05654-7

[6] Žák, P. Habel, J., Pelánová, Z.: Comprehensive solution of the indoor lighting, LUMEN V4, MEE Világítástechnikai Társaság, 26-29 (2014), ISBN 978-963-9299-21-4

[7] Kobav, M. Bizjak, G.: Development of a substitutive light source for indoor daylight calculations, Building and Environment 40, 1611-1618 (2005)

\section{Authors:}

Ing. Zuzana Panská, České vysoké učení technické v Praze, Fakulta elektrotechnická, Technická 2, 16627 Praha 6, Czech Republic, e-mail:pelanzuz@fel.cvut.cz,

Ing. Petr Žák, Ph.D., České vysoké učení technické v Praze, Fakulta elektrotechnická, Technická 2, 16627 Praha 6, Czech Republic,

prof. Ing. Jiři Habel,DrSc., České vysoké učení technické v Praze, Fakulta elektrotechnická, Technická 2, 16627 Praha 6, Czech Republic, 